Martina Klost, Stephan Drusch

\title{
Structure formation and rheological properties of pea protein-based gels
}

Journal article | Accepted manuscript (Postprint)

This version is available at https://doi.org/10.14279/depositonce-9555

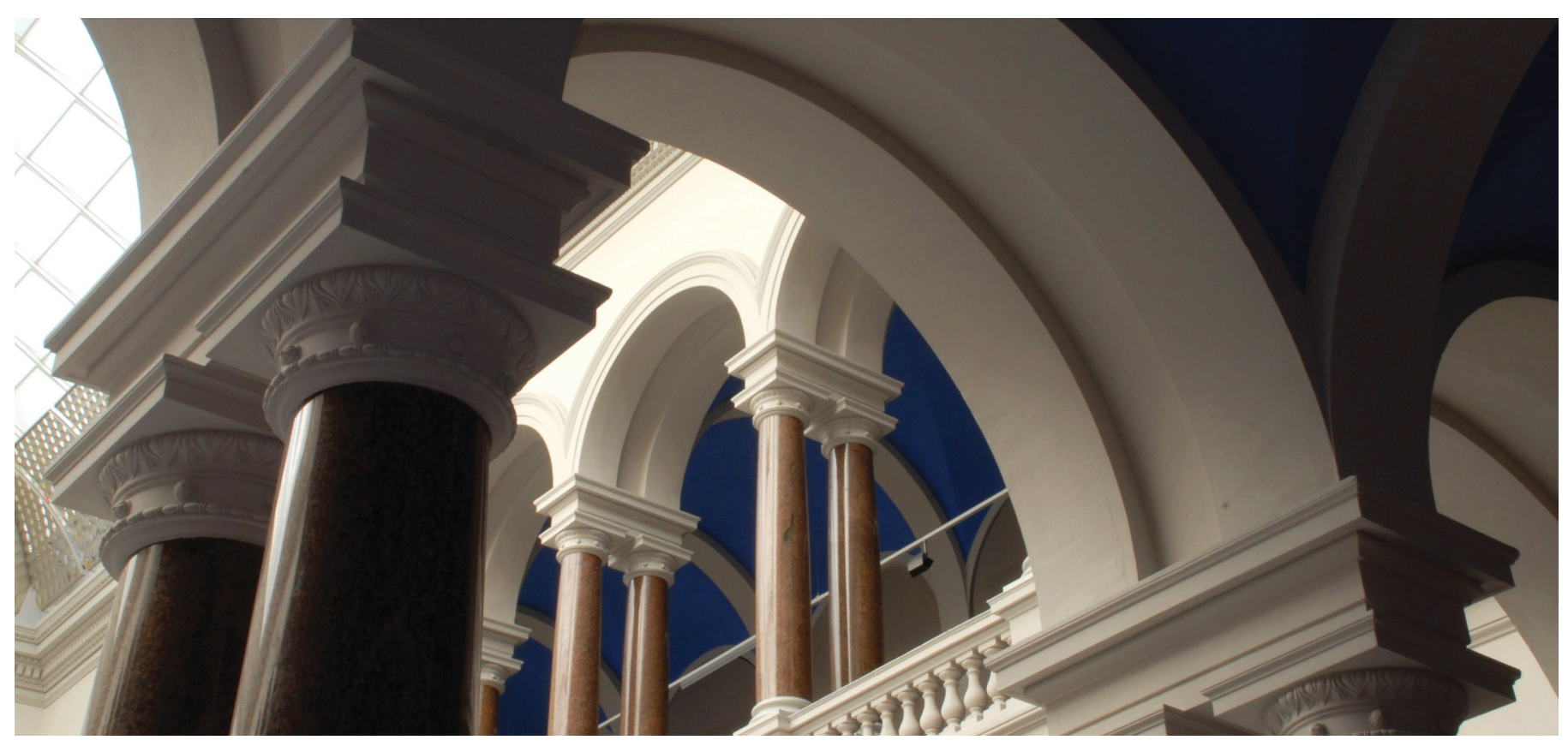

Klost, M., \& Drusch, S. (2019). Structure formation and rheological properties of pea protein-based gels.

Food Hydrocolloids, 94, 622-630. https://doi.org/10.1016/j.foodhyd.2019.03.030 


\title{
Structure formation and rheological properties of pea protein-based gels
}

\author{
Klost, M. ${ }^{1,2}$ and S. Drusch ${ }^{1,2}$ \\ ${ }^{1}$ Technische Universität Berlin, Department of Food Technology and Food Material Science, Königin-Luise-Str. 22, 14195 \\ Berlin \\ ${ }^{2}$ NutriAct - Competence Cluster Nutrition Research Berlin-Potsdam \\ * Correspondence: martina.klost@tu-berlin.de; Tel.: +49-30-314-71824
}

\begin{abstract}
:
Nutritional recommendations for the elderly, but also the general public, include incorporation of plant proteins in the diet, an increase in the intake of $\Omega-3$ fatty acids and an increase in intake of dietary fibre. Protein structure and structuring behaviour of plant proteins differ from that of milk proteins. Therefore, the aim of the presented study was to characterise the structuring process and resulting structure of yoghurt-style gels containing $10 \%$ pea protein with and without addition of nutritionally recommended ingredients like rapeseed-oil and/or commercial oat fibre. Rheological measurements were combined with microscopy for sample characterisation. Generally, all studied formulations were able to form acid induced gels via fermentation. The acidification led to a two-phase gelation process resulting in thick gels that showed mainly weak rheological behaviour. Supplementation with oil and/or fibre resulted in an increase of the relative concentration of pea protein in the aqueous phase and led to a strong increase in the complex shear modulus $\left|\mathrm{G}^{*}\right|$ as well as the maximum structuring velocity $\mathrm{d}\left|\mathrm{G}^{*}\right| / \mathrm{dt}$. These effects need to be considered when tailoring yoghurt-style gels with high consumer acceptance.
\end{abstract}

Keywords: plant protein, gelation, fermentation, rheology, oat fibre, rapeseed-oil

\section{Introduction}

In the light of steadily increasing life expectancy in developed countries, improvement of health and well-being in general and healthy aging in particular are key challenges. It is known, that plant proteins may be beneficial in the prevention of chronic degenerative diseases (KrajcovicovaKudlackova, Babinska, \& Valachovicova, 2005). Additionally the demand for an increased fibre intake as well as the benefits that derive from the intake of unsaturated fatty acids (European Food Safety Authority, 2010b, 2010a) are to be considered when designing products to support healthy ageing. A suitable product-category for incorporation of the required amounts of protein, oil and fibre are yoghurttype gels. Yoghurt is associated with protein-rich food and has a high consumer acceptance (Banovic et al., 2018). Traditionally, yoghurt is based on dairy ingredients. The casein fraction of milk possesses a unique micellar structure, which leads to a specific gelation behaviour. (Lee \& Lucey, 2010). The gel structure forms at the isoelectric point (IEP) of casein during acidification of milk (Lee \& Lucey, 2010) and dairy-based yoghurt gels are particulate on a microscopic scale (Lucey \& Singh, 1997).

When partly or fully substituting dairy proteins during yoghurt processing the underlying mechanisms for gel formation are similar. There has already been extensive research on many aspects of a variety of plant-derived proteins. Besides cereal and oil seed proteins, pulse proteins have been in focus in the past. Within the pulse family interest in pea is increasing due to its ability to easily grow all over the world and an easily removable hull (Day, 2013). Molecular interactions during gel formation are mainly non-covalent in nature and may include hydrogen bonding, electrostatic and hydrophobic interactions (Kohyama, Sano, \& Doi, 1995). However, due to differences in protein structure and course of fermentation plant protein-based systems may show very different structuring behaviour. Several studies focused on partial replacement of dairy proteins in yoghurt and the impact on yoghurt structure (Yousseef, Lafarge, Valentin, Lubbers, \& Husson, 2016; Zare, Boye, Champagne, Orsat, \& Simpson, 2013) and taste (Denkova, Yanakieva, Denkova, Dobrev, \& Kozludzhova, 2013; Yousseef et al., 2016). In contrast, the structuring behaviour and gel properties upon fermentation of pea protein alone have not 
been investigated in detail. The few studies covering pea protein used glucono- $\delta$-lactone for acidification (Ben-Harb et al., 2017; Mession, Chihi, Sok, \& Saurel, 2015). However it is well described in literature that kinetics of acidification and structure formation during microbial fermentation may differ from kinetics when using glucono- $\delta$-lactone (Grygorczyk \& Corredig, 2013).

It is widely accepted, that proteins need to undergo some heat induced unfolding and preaggregation in order to be able to form gels by acidification. Therefore, studies generally employ a heating step above the denaturation temperature of the protein to ensure sufficient network formation during acidification. However, there are studies that report incomplete unfolding of globular proteins even above the denaturation temperature (Hirose, 1993) and structural changes below the denaturation temperature (Miriani, Keerati-u-rai, Corredig, Iametti, \& Bonomi, 2011), where proteins may assume a molten globule state. N. Chen, Zhao, Chassenieux, \& Nicolai, 2016 described a strong time dependence for the formation of self-similar aggregates in soy globulins at a wide range of temperatures (50 to $95^{\circ} \mathrm{C}$ ). The same authors also described the ability of native soy globulins to form self-assembled aggregates and found this ability to be concentration- and charge-dependent (N. Chen, Zhao, Chassenieux, \& Nicolai, 2016a). Moreover, hydrophobic interactions between exposed groups have been described to lead to aggregation between globular protein molecules while still in the molten globule state (Ochenduszko \& Buckin, 2010). It is therefore likely that pea protein in concentrated suspensions will be able to pre-aggregate to a certain extend below the denaturation temperature.

Structure formation may additionally be affected by supplementation with other food constituents. When considering the literature on yoghurt supplementation with various fibres it becomes obvious, that textural properties are affected in various ways as shown for orange fibre (Sendra et al., 2010), passionfruit fibre (Espírito-Santo et al., 2013), asparagus fibre (Sanz, Salvador, Jiménez, \& Fiszman, 2008), pea fibre (Damian \& Olteanu, 2014), soy, rice, oat, corn, sugar beet fibre (Fernández García \& McGregor, 1997), wheat bran fibre (Aportela-Palacios, Sosa-Morales, \& Vélez-Ruiz, 2005) and fibre rich pineapple peel (Sah, Vasiljevic, McKechnie, \& Donkor, 2016). Since commercial fibre may vary in the ratio of soluble and insoluble constituents, particle size and resulting functional properties, little is known about the general mechanisms behind these effects. Insoluble particles may act as active or inactive fillers. While inactive fillers have little chemical affinity for the matrix, active fillers normally interact strongly with the gel (J. Chen \& Dickinson, 1998) and influence water-holding, microstructural and rheological properties (Gu, Campbell, \& Euston, 2009; Keogh \& O'Kennedy, 1998; C. Tang, Chen, \& Foegeding, 2011). The ability of fillers to interact with the gel matrix - making them active or inactive -depends on the filler particles surface properties (Dickinson \& Chen, 1999). To our knowledge, so far there is no literature available on fibre-protein-interactions in protein-based gels or on the categorisation of fibres into active or inactive fillers. The oat fibre used in this study contained a minimum of $90 \%$ insoluble fibre of which $75 \%$ are cellulose. The remaining part most likely consists of hemicelluloses and lignin. Cellulose, hemicelluloses and lignin are described to be mostly non-ionic. While cellulose and hemicelluloses carry hydroxyl-groups at their surface, making them hydrophilic, lignin is more hydrophobic. Molecular properties similar to cellulose and hemicelluloses can be observed in intact starch granules ( $\alpha(1-4)$-linked D-glucose). From literature it is known, that crosslinked waxy maize starch does not directly interact with milk proteins in acidified milk gels (Azim, Alexander, Koxholt, \& Corredig, 2010).

The supplementation of acid induced protein gels with oil has previously been described in the context of filled emulsion gels by various authors (Ben-Harb et al., 2017; Dickinson, 2012; Gu et al., 2009; Li, Kong, Zhang, \& Hua, 2012; C. Tang et al., 2011). Gel systems that contain emulsified oil droplets are known as emulsion gels. Dickinson, 2012 distinguishes between emulsion-filled protein gels and protein-stabilised emulsion gels based on the dominating network structure. Literature usually considers protein-stabilised oil-droplets as active fillers due to their affinity to the gel matrix (Dickinson, 2012) with their role in the gel network strongly depending on the interactions between interfacial and 
bulk proteins (C. Tang et al., 2011). Active fillers are known to decrease tan $\delta$ (Dickinson $\&$ Chen, 1999; Gu et al., 2009) and may increase the storage modulus G' (Ben-Harb et al., 2017; Dickinson \& Chen, 1999).

The presented study aims to investigate the structuring process during fermentative gelation of pea protein and the properties of the gel as well as the effect of supplementation with nutritionally favourable food ingredients like rapeseed oil and/or oat fibre. The experimental design, ingredient choices and sample compositions of this study are therefore motivated by nutritional recommendations for the ageing population: increased intake of plant protein, dietary fibre and unsaturated fatty acids.

\section{Materials and Methods}

Within this study, different samples were formulated which contained pea protein $(\mathrm{P})$, or pea protein in combination with rapeseed oil (PO), oat fibre (PF) or both (POF). For the characterisation of structure formation and gel properties, rheological measurements were performed during and after the fermentation process. Conclusions drawn on the structure were supported by microscopy.

Dried peas were supplied by Emsland-Stärke GmbH (Emlichheim, Germany), ADM WILD Europe GmbH\&Co.KG (Hamburg, Germany) provided rapeseed oil and Herbafood Ingredients GmbH (Werder (Havel), Germany) the oat fibre Herbacel Classic Plus HF 04. The oat fibre contains 68\% cellulose (as determined by determination of glucose content after Seaman-Hydrolysis) and a minimum total of $90 \%$ insoluble fibre according to the manufacturer's specification. Soluble fibre content accounts for a maximum of 5.6\% with negligible amounts of pectic substances (galacturonic acid content below $0.5 \%$ as determined by m-hydroxydiphenyl method). All lab chemicals were purchased from Carl Roth $\mathrm{GmbH}+\mathrm{Co.KG}$ (Karlsruhe, Germany), Merck and Sigma Aldrich (both Life Science at Merck, Darmstadt, Germany) and were of analytical grade. Yoghurt culture containing Lactobacillus delbrueckii ssp. bulgaricus and Streptococcus thermophilus (YC-X11 Yo-Flex®) was provided by Chr. Hansen Holding A/S (Hoersholm, Denmark).

Pea protein was produced on lab scale as previously described in more detail (Klost \& Drusch, 2019). Briefly, dry peas were ground and the flour was dispersed in $0.0375 \mathrm{M} \mathrm{NaOH}$ leading to an initial $\mathrm{pH}$ value of approximately 8.7 which dropped to just above $\mathrm{pH} 8$ during the extraction time. After 2.5 $\mathrm{h}$ of extraction at room temperature, the sample was centrifuged $\left(5000 \mathrm{~g}, 20^{\circ} \mathrm{C}\right.$ for 30 minutes $)$ and the supernatant was lyophilized. The resulting protein powder had a protein-content of $53.8 \%, 3.5 \%$ water, $1.6 \%$ starch, $7 \%$ sucrose, $4 \%$ fat and $\sim 17 \%$ raffinose family sugars, calculated as stachyose.

\subsection{Characterisation of pea protein in solution}

Unfolding and pre-aggregation of protein molecules is generally acknowledged as a prerequisite for acid induced gelation of proteins. Therefore, the pea protein solution was characterised prior to fermentation via intrinsic fluorescence and temperature-sweep rheology to determine protein unfolding and pre-aggregation in the protein solutions during the applied heat treatment.

In intrinsic fluorescence measurements, a protein-solution $(0.1 \%(\mathrm{w} / \mathrm{w}), \mathrm{pH} 6.5)$ was exited at a fixed wavelength $(290 \mathrm{~nm})$ and the emission-wavelength was scanned between 300 and $400 \mathrm{~nm}$ (Cary Eclipse Fluorescence Spectrophotometer (Agilent Technologies, Victoria, Australia)). The wavelength at maximum emission was then used to characterise structural changes as a red shift in the maximum emission wavelength generally indicates protein unfolding. Additionally, protein solutions $(10 \%(\mathrm{w} / \mathrm{w})$, $\mathrm{pH}$ 6.5) were swept in a rheometer (MCR 502, Anton Paar, Austria (couette system CC 27) (f $=1 \mathrm{~Hz}$, deformation $\gamma=0.1 \%$ ) to determine aggregation via increase in viscosity.

Both experiments were conducted at the same heating regime: heating from 20 to $60{ }^{\circ} \mathrm{C}$ with a heating rate of $1 \mathrm{~K} / \mathrm{min}$ followed by a holding time of 60 minutes at $60^{\circ} \mathrm{C}$ and subsequent heating from 60 to $80{ }^{\circ} \mathrm{C}$ (rate $1 \mathrm{~K} / \mathrm{min}$ ) and further 15 minutes of holding. In the rheometer values of temperature $\mathrm{T}$ and complex viscosity $\left|\eta^{*}\right|$ were taken at regular intervals. Scans in the fluorescence Spectrophotometer 
were performed before heating, after holding at $60^{\circ} \mathrm{C}$ and after holding at $80^{\circ} \mathrm{C}$. The experiments were carried out in duplicate.

\subsection{Relative protein concentration depending on sample composition and water retention capacity of supplements}

Table 1 shows the composition of all samples. The protein-concentration in all samples was kept constant at $10 \%(\mathrm{w} / \mathrm{w})$. Consequently, the total amount of water in the samples decreased with increasing supplementation. Additionally, the water retention capacity of the fibre (5.2 $\mathrm{g}$ water/g fibre) decreases the availability of water even further. The relative protein concentration in the samples is considered to be the concentration that can be calculated when the amount of protein is only related to the amount of available water instead of the net weight of the sample. Calculated values are given in Table 1.

Table 1 composition of the samples (content in $100 \mathrm{~g}$ sample), the water retention capacity of the fibre, the calculated available water and the relative protein content of all samples

\begin{tabular}{l|ccccccc}
\hline Sample & $\begin{array}{c}\text { Pea } \\
\text { protein } \\
{[\mathrm{g}]}\end{array}$ & $\begin{array}{c}\mathrm{HCl} 0.025 \\
\mathrm{M}\end{array}$ & $\begin{array}{c}\text { Oil } \\
{[\mathrm{g}]}\end{array}$ & $\begin{array}{c}\text { Fibre } \\
{[\mathrm{g}]}\end{array}$ & $\begin{array}{c}\text { Water retention } \\
\text { capacity }\end{array}$ & $\begin{array}{c}\text { Available } \\
\text { water } \\
{[\mathrm{g} \text { water/g fibre }]}\end{array}$ & $\begin{array}{c}\text { Relative protein } \\
\text { content } \\
{[\%]}\end{array}$ \\
\hline P & 18.53 & 81.47 & - & - & - & 81.47 & 10.83 \\
PO & 18.53 & 77.47 & 4 & - & - & 77.47 & 11.27 \\
PF & 18.53 & 78.47 & - & 3 & 5.2 & 57.67 & 13.96 \\
POF & 18.53 & 74.47 & 4 & 3 & 5.2 & 53.67 & 14.64 \\
\hline
\end{tabular}

(Samples: $\mathrm{P}=$ pea protein, $\mathrm{PO}=$ pea protein and rapeseed-oil, $\mathrm{PF}=$ pea protein and fibre, $\mathrm{POF}=$ pea protein, rapeseed-oil and fibre)

\subsection{Sample preparation, fermentation and analysis of structure formation}

Pea protein was dissolved in $0.025 \mathrm{M} \mathrm{HCl}$ to achieve a final protein concentration of $10 \%(\mathrm{w} / \mathrm{w})$ and a $\mathrm{pH}$ of approximately 6.5. The suspension was mixed by rotor-stator homogenisation (Ultraturrax T25 basic, IKA, Germany, $90 \mathrm{~s}, 21500 \mathrm{rpm}$ ). In case of fibre supplementation, 3\% (w/w) fibre were suspended in the $0,025 \mathrm{M} \mathrm{HCl}$, and passed through a high-pressure homogeniser (Panda Plus, Niro Soavi, Germany) at 7.5 MPa. Pea-protein was then dissolved in the fibre-dispersion. The protein or protein-fibre dispersion was heated to $60^{\circ} \mathrm{C}$ for $60 \mathrm{~min}$ for pasteurisation adjusted from (Krämer, 1997) who described low temperature pasteurisation at $65^{\circ} \mathrm{C}$ and 30 minutes. Heating was followed by cooling at room temperature for $15 \mathrm{~min}$. The pasteurisation-temperature was chosen just below the denaturation temperature of the pea protein in order to not overly damage the protein structure while achieving some unfolding to induce gelation via fermentation later. Afterwards, the samples where passed through a high-pressure homogeniser (Panda Plus, Niro Soavi, Germany) at $3 \mathrm{MPa}$. In case of supplementation with rapeseed-oil, $4 \%$ (w/w) oil was added prior to homogenising. Starter culture (YC-X11 Yo-Flex ${ }^{\circledR}$ ) was added, and after 10 minutes of stirring the blend was fermented in a water bath at $43{ }^{\circ} \mathrm{C}$ for $18 \mathrm{~h}$, while constantly tracking the $\mathrm{pH}$-value (SI Analytics Lab 865, Xylem, USA).

Gels and gelation processes can be monitored by rheology. During gelation the crossover of storage modulus G' and loss modulus G" (loss-factor $\tan \delta=1$ ) can be considered as "gel-point" (Morris, Nishinari, \& Rinaudo, 2012) and the structuring velocity can be used to estimate the end of the structuring process. Therefore, approximately $20 \mathrm{~mL}$ of the mix were fermented in a rheometer for 18 hours (Rheometers were Physica UDS and MCR 502, Anton Paar, Austria (couette system Z 3 DIN and CC 27 respectively) ( $f=1 \mathrm{~Hz}$, deformation $\gamma=0.1 \%$ ). At least one repetition for each experiment was performed in each rheometer) in order to study structure formation. $\left|\mathrm{G}^{*}\right|$ and $\tan \delta$ were chosen for the rheological characterisation of the structuring process. They are defined as 


$$
\left|G^{*}\right|=G^{\prime}+i \cdot G^{\prime \prime}
$$

and

$$
\tan \delta=\frac{\mathrm{G}^{\prime \prime}}{\mathrm{G}^{\prime}}
$$

For the characterisation of maximum structuring velocity the first derivative of $\left|\mathrm{G}^{*}\right|\left(\mathrm{d} \mid \mathrm{G}^{*} / \mathrm{dt}\right)$ was calculated (Grosso \& Rao, 1998) using the software Origin 9.0, OriginLab, USA .All samples were prepared in triplicate and stored at $6{ }^{\circ} \mathrm{C}$ for $24-30 \mathrm{~h}$ after fermentation.

\subsection{Rheology of fully set gels}

Rheology classifies gels into strong and weak gels. Strong and weak gels behave differently in texture and rheology-experiments. A strong gel is characterised by low dependence of G' and G' on frequency, values of G' that exceed G' by at least one order of magnitude and linear relation between $\log \left|\eta^{*}\right|$ and $\log \omega$ with a slope close to -1 (Morris et al., 2012). Additionally, strong gels remain strain independent up to deformations of $25 \%$, but will rupture and be irreversibly destroyed under larger deformations (Ross-Murphy \& Shatwell, 1993). In contrast, weak gels may begin to flow at an increase of frequency and deformation, but are able to restructure afterwards (Ross-Murphy \& Shatwell, 1993).

In the present study, all rheology tests of fully set gels after 24-30 hours were performed at the Physica UDS, Anton Paar, Austria. $\left|\mathrm{G}^{*}\right|_{24-30 \mathrm{~h}}$ and $\tan \delta_{24-30 \mathrm{~h}}(\gamma=0.1 \%$ and $1 \mathrm{~Hz})$ were measured after sample-resting at $6{ }^{\circ} \mathrm{C}$ in beakers. Prior to measurement, the samples were carefully spooned into the rheometer cup. Frequency sweeps were carried out at a constant deformation of $\gamma=0.1 \%$ and frequencies ranging from 0.01 to $10 \mathrm{~Hz}$. For evaluation, the slopes of $\log G^{\prime}, \log G^{\prime}$ ' and $\log \left|\eta^{*}\right|$ over $\log \omega=2 \pi \mathrm{f}$ were calculated in order to characterise gel behaviour. Amplitude sweeps were carried out at a frequency of $1 \mathrm{~Hz}$ and amplitudes from $\gamma=0.1 \%$ to $\gamma=5000 \%$. The deformation at the end of the linear viscoelastic regime (LVE) was calculated as the largest deformation where $\left|\mathrm{G}^{*}\right|$ deviates from the original value by less than 5\% (Mezger, 2006). The yield point is the point where $\tan \delta$ becomes $>1$ (DIN Technical Report No. 143, 2005) and the deformation at this point was used for further evaluation. For thixotropy tests according to DIN SPEC 91143-2, 2012, oscillation at $\gamma=0.1 \%$ and $\mathrm{f}=1 \mathrm{~Hz}$ was applied for $100 \mathrm{~s}$, followed by shearing at a rate of $\gamma=200 \mathrm{~s}^{-1}$ for $2 \mathrm{~min}$ and another $10 \mathrm{~min}$ of oscillation. The loss of structure was calculated as

$$
\Delta G^{\prime}=\left|100 \%-\frac{G^{\prime} \text { end } 100 \%}{G_{\text {start }}^{\prime}}\right|
$$

and

$$
\Delta \mathrm{G}^{\prime \prime}=\left|100 \%-\frac{\mathrm{G}^{\prime \prime} \text { end }}{\mathrm{G}^{\prime \prime} \text { start }}\right|
$$

\subsection{Scanning electron microscopy (SEM)}

After storage for $24 \mathrm{~h}$ at $6{ }^{\circ} \mathrm{C}$, approx. $3 \mathrm{~g}$ of fermented sample were filled into $20 \mathrm{~mL}$ plastic beakers, frozen by immersing the beaker into liquid nitrogen and stored at $-20^{\circ} \mathrm{C}$ prior to lyophilisation. Lyophilised samples were carefully broken into pieces and the breakage site was gold sputtered in a sputter coater SCD 030 (Balzers, Wiesbaden-Nordenstadt, Germany). The microstructure was analysed by SEM at the Center for Electron Microscopy (ZELMI), Technische Universität Berlin, Berlin, Germany by the S-2700 scanning electron microscope (Hitachi, Tokyo, Japan); magnification was 300x and 3000x. SEM was carried out once for each formulation. 


\subsection{Statistic evaluation}

All fermentation and rheology experiments were carried out in triplicate and evaluated using a one factorial ANOVA followed by a post hoc test (Tukey) to determine differences between samples with different formulations (Origin 9.0, OriginLab, USA). Normal distribution was tested by Kolmogorov-Smirnov-Test.

\section{Results and Discussion}

\subsection{Characterisation of pea protein-unfolding and aggregation behaviour upon heating}

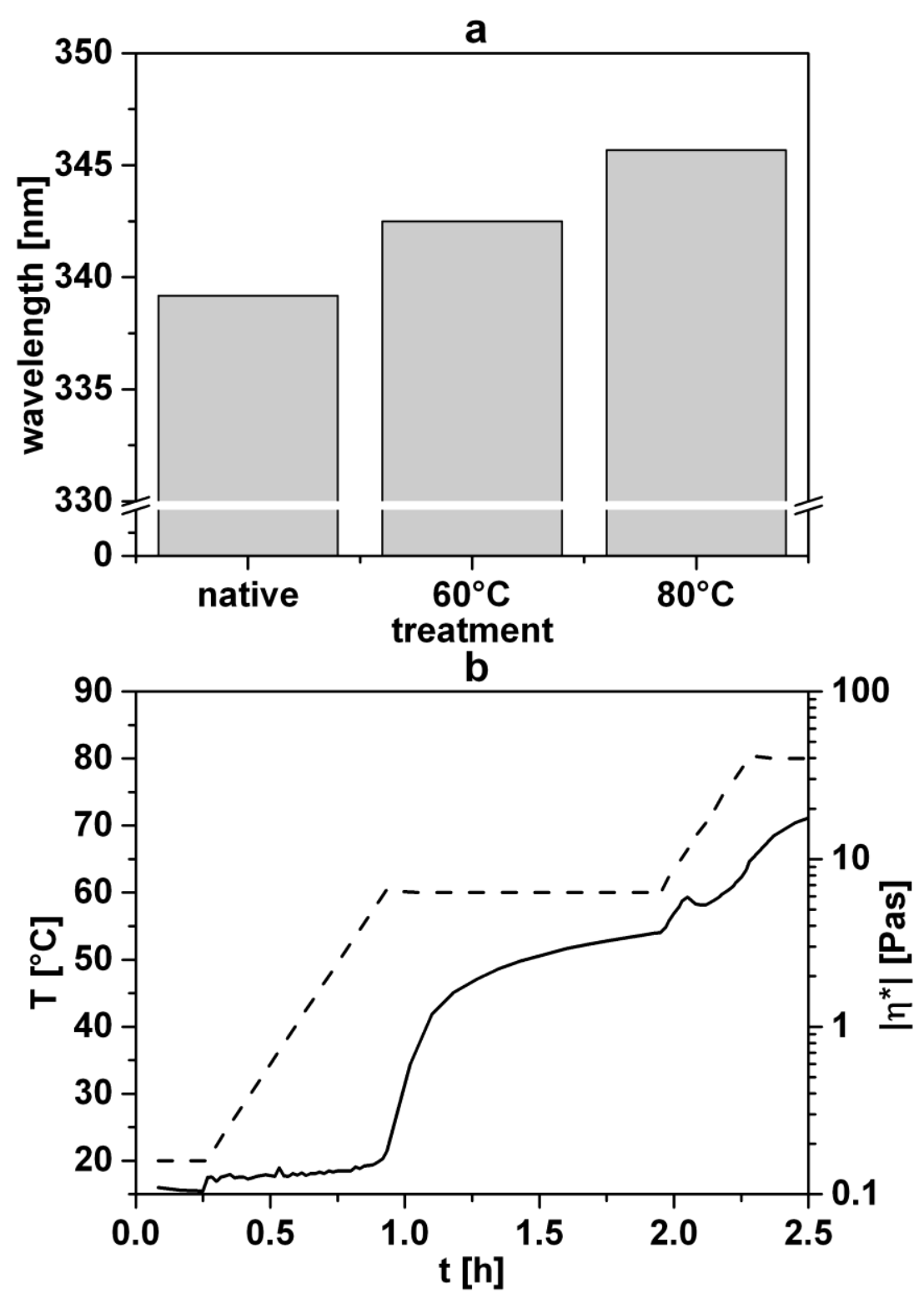

Fig 1 change in intrinsic fluorescence (a) and complex viscosity $\left(\left|\eta^{*}\right|\right)$ (b) induced by heating $10 \%$ pea protein to 60 and $80{ }^{\circ} \mathrm{C}$. $\left(\left|\eta^{*}\right|\right.$ closed line, $T$ dashed line)

Upon heating of diluted pea protein solution to $60^{\circ} \mathrm{C}$ followed by holding for 60 minutes, in intrinsic fluorescence measurements a red shift of approximately $3 \mathrm{~nm}$ occurred. Further heating to $80^{\circ} \mathrm{C}$ led to a further shift of additional $3 \mathrm{~nm}$ (figure 1a). Even though the red shift is more pronounced at $80^{\circ} \mathrm{C}$, it becomes obvious, that with the applied heating regime the pea protein used in this study already undergoes considerable unfolding and exposure of previously buried hydrophobic regions, which will 
enable it to form intermolecular interactions, despite not being heated beyond the denaturation temperature. This is also supported by the results from rheological temperature sweep (figure 1b). In this experiment a $10 \%(\mathrm{w} / \mathrm{w})$ protein-solution was heated to $60^{\circ} \mathrm{C}$, held for 60 minutes and then heated to $80^{\circ} \mathrm{C}$ and held for an additional 15 minutes. Just below $60{ }^{\circ} \mathrm{C}$ the complex viscosity $\left|\eta^{*}\right|$ began to increase from approximately 1.3 Pas to $3.7 \mathrm{Pas}$ at the end of the holding time at $60^{\circ} \mathrm{C}$ where $\mathrm{G}$ ' exceeded G' by almost an order of magnitude. $\left|\eta^{*}\right|$ reached a local maximum at of 5.9 Pas at $66{ }^{\circ} \mathrm{C}$ and then continued to increase to 18.3 Pas after holding for 15 minutes at $80^{\circ} \mathrm{C}$. Considering data from intrinsic fluorescence and rheological temperature sweeps, we propose some unfolding of the protein at $60{ }^{\circ} \mathrm{C}$ accompanied by intermolecular interactions, which leads to an increase in viscosity. As heat-induced aggregation has been described to be a prerequisite for acid induced gelation, we expect the heat treatment applied to be sufficient for use in further experiments. However, from the data it also becomes obvious, that unfolding and pre-aggregation would be more pronounced in samples that were heated above the denaturation temperature. However, since the desired protein-content of $10 \%$ is considerably higher than that of milk-based yoghurts, there is no need to take full advantage of intermolecular interactions and pre-aggregation as it may lead to an undesirably strong texture and consistency of the final gels.

\subsection{Structure-formation during fermentation}

This section covers the changes of $\mathrm{pH}$ value and complex shear modulus $\left|\mathrm{G}^{*}\right|$ during and after fermentation as well as the influence of supplementation with rapeseed oil and / or oat fibre on structure formation. By combining those results with results from $\zeta$-potential measurement and scanning electron microscopy, we deduce information on the nature of the structuring process and on the gel structure itself.

The main driving force in network formation and structuring of acid induced protein gels is the decrease in $\mathrm{pH}$-value. This in turn leads to changes in electrostatic properties and molecular interactions and therefore to an increase in the structure parameters $\left|G^{*}\right|, G^{\prime}, G^{\prime \prime}$ and a decrease in $\tan \delta$. Upon fermentation of pea protein concentrate dispersions with and without oil and/or fibre supplementation, a major drop in $\mathrm{pH}$-value from $\sim \mathrm{pH} 6.6$ to $\sim \mathrm{pH} 4.7$ (table 3) - caused by microbial digestion of sucrose from pea-protein to lactic acid-occurred within the first six hours of fermentation time (figure 2 a) and reached its maximum velocity after approx. 2.6 to 2.9 hours with no significant differences between the samples (table 2). This is in contrast with Fernández García \& McGregor, 1997 and McCann, Fabre, \& Day, 2011 who described an accelerated acidification rate for various fibres and linked this to a supply of additional nutrients and the natural acidity of the fibres respectively. However, the oat fibre used in our study contains a maximum of $5 \%$ soluble fraction and is therefore not believed to supply relevant amounts of additional nutrients. As expected, the drop in $\mathrm{pH}$ was accompanied by a decrease in the loss factor $\tan \delta$ below one as indicated by complex shear modulus $\left|\mathrm{G}^{*}\right|$ increasing rapidly (figure $2 \mathrm{~b}$ ) and G' exceeding the loss modulus G'" (data not shown). Structuring velocity reached its maximum after approximately 2.35 hours in all samples and significantly increased in magnitude from $127.4 \pm 8.5$ $\mathrm{Pa} / \mathrm{h}(\mathrm{P})$ to $308.0 \pm 30.8 \mathrm{~Pa} / \mathrm{h}$ (POF) with increasing fortification (table 2 ). $\left|\mathrm{G}^{*}\right|$ began to increase between pH 6.2 and 6.5 and a first maximum in the slope was seen around $\mathrm{pH} 6$ followed by a decline until approximately $\mathrm{pH} 5.5$ and a steeper increase toward $\mathrm{pH} 4.8$ (figure $2 \mathrm{c}$ ) indicating a two-step gelation process. This behaviour was differently pronounced but similar for all samples (table 2). 
a
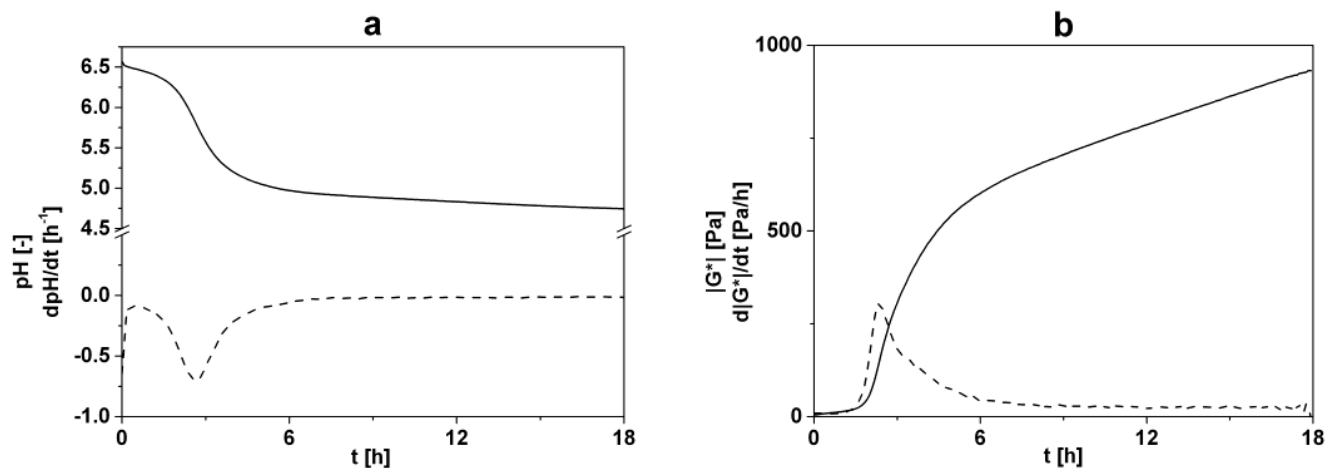

C

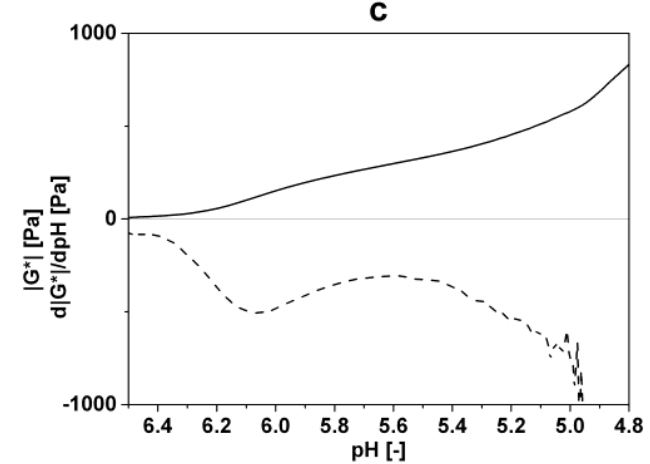

Fig 2 development of $p H$ (a) and complex shear modulus $\left|G^{*}\right|$ (b) over time and $\left|G^{*}\right|$ over $p H$ (c) during the fermentation process of samples containing oil and fibre. Development of the parameters (closed lines) is shown alongside their first derivations (dashed lines). 
Table 2 maximum values for $\mathrm{d} \mid \mathrm{G}^{*} / \mathrm{dt}$ and $\mathrm{dpH} / \mathrm{dt}$ and the corresponding values for time and $\mathrm{pH}$. $\mathrm{pH}$ values at maximum and minimum values for $\mathrm{d} \mid \mathrm{G}^{*} / / \mathrm{dpH}$. (Samples: $\mathrm{P}=$ pea protein, $\mathrm{PO}=$ pea protein and rapeseed-oil, $\mathrm{PF}=$ pea protein and fibre, $\mathrm{POF}=$ pea protein, rapeseed-oil and fibre)

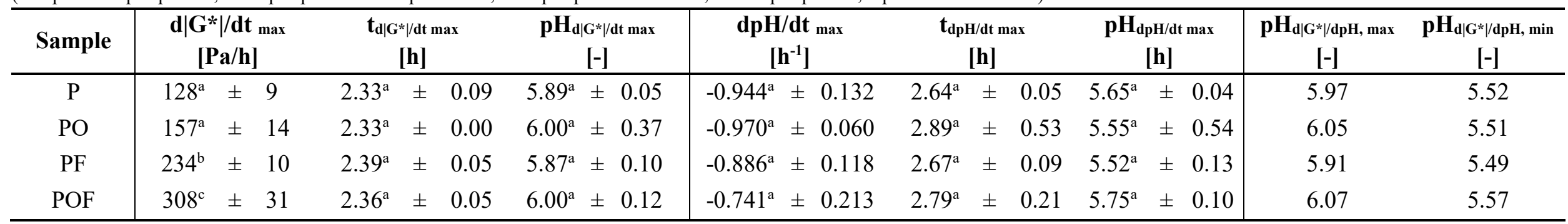

*Different letters within a column denote significant differences between individual samples as found by one factorial ANOVA followed by Tukey postHoc Test

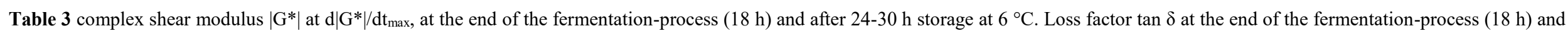
after 24-30 h storage at $6^{\circ} \mathrm{C}$.

(Samples: $\mathrm{P}=$ pea protein, $\mathrm{PO}=$ pea protein and rapeseed-oil, $\mathrm{PF}=$ pea protein and fibre, $\mathrm{POF}=$ pea protein, rapeseed-oil and fibre)

\begin{tabular}{|c|c|c|c|c|c|c|c|c|c|c|c|c|c|}
\hline \multirow{2}{*}{$\frac{\text { Sample }}{\mathrm{P}}$} & $\begin{array}{c}\left|\mathbf{G}^{*}\right|_{\mathbf{d} \mid \mathbf{G}^{*} / \mathbf{d t}} \\
\max [\mathrm{Pa}] \\
\end{array}$ & $\begin{array}{c}\left|\mathbf{G}^{*}\right|_{\text {ferm. end }} \\
{[\mathrm{Pa}]} \\
\end{array}$ & \multicolumn{3}{|c|}{$\left|\mathrm{G}^{*}\right|_{24-30 \text { h }}[\mathrm{Pa}]$} & \multirow{2}{*}{$\frac{\tan \boldsymbol{\delta}_{\text {ferm. start }[-]}}{>1}$} & $\tan \delta_{\text {ferm. end }}[-]$ & $\tan \delta_{24-30 h}[-]$ & \multicolumn{3}{|c|}{$\mathbf{p H}_{\text {ferm,start }}[-]$} & \multicolumn{2}{|c|}{$\mathbf{p H}_{\text {ferm, end }}[-]$} \\
\hline & $44^{\mathrm{a}} \pm 6.4$ & $452^{a} \pm 27$ & $720^{\mathrm{a}}$ & \pm & 25 & & $0.164^{\mathrm{a}} \pm 0.005$ & \pm 0.002 & $6.55^{\mathrm{a}}$ & \pm & 0.03 & $4.69^{\mathrm{a}}$ & \pm 0.03 \\
\hline $\mathrm{PO}$ & $62^{\mathrm{a}} \pm 6.1$ & $521^{\mathrm{a}} \pm 59$ & $741^{\mathrm{a}}$ & \pm & 46 & $>1$ & $0.146^{\mathrm{a}} \pm 0.015$ & $0.255^{\text {b.c }} \pm 0.001$ & $6.56^{\mathrm{a}}$ & \pm & 0.09 & $4.65^{\mathrm{a}}$ & \pm 0.04 \\
\hline $\mathrm{PF}$ & $97^{\mathrm{b}} \pm 5.8$ & $842^{b} \pm 92$ & $1295^{\mathrm{b}}$ & \pm & 80 & $0.669 \pm 0.086$ & $0.159^{\mathrm{a}} \pm 0.004$ & $0.261^{\mathrm{a} . \mathrm{b}} \pm 0.003$ & $6.53^{\mathrm{a}}$ & \pm & 0.05 & $4.68^{\mathrm{a}}$ & \pm 0.03 \\
\hline POF & $149^{c} \pm 19.7$ & $932^{b} \pm 111$ & $1388^{\mathrm{b}}$ & \pm & 37 & $0.710 \pm 0.066$ & $0.145^{\mathrm{a}} \pm 0.004$ & $0.248^{c} \quad \pm 0.007$ & $6.58^{\mathrm{a}}$ & \pm & 0.02 & $4.75^{\mathrm{a}}$ & \pm 0.11 \\
\hline
\end{tabular}

*Different letters within a column denote significant differences between individual samples as found by one factorial ANOVA followed by Tukey postHoc Test 
The onset of increase in G' and the first maximum in structuring velocity at $\mathrm{pH} 6$ took place distinctly above the isoelectric points (IEP) of the two major pea globulins ( $\mathrm{pH} 5.5$ for vicilin and $\mathrm{pH}$ 4.8 for legumin (Danielsson, 1950)). This is in contrast with the structuring process of yoghurts based on milk protein, where the formation of a three dimensional network occurs close to the isoelectric point (Lee \& Lucey, 2010). Upon acidification with glucono- $\delta$-lactone, Ben-Harb et al., 2017 described faster structuring in pea protein samples than in those consisting of milk protein. They did however not give any $\mathrm{pH}$ values at which the structuring occurred. Mession et al., 2015 reported gel-points at $\mathrm{pH} 6.7$ for pea protein acidified with glucono- $\delta$-lactone but offered no reference to this value being distinctly above the isoelectric point. Some explanations can be found in Grygorczyk \& Corredig, 2013, who previously reported a gel-point at $\mathrm{pH} 6.29 \pm 0.05$ for soy-protein acidified via fermentation. They ascribe the early onset of structuring to aggregation of $11 \mathrm{~S}$ basic subunits with $\beta$ subunits of $7 \mathrm{~S}$ molecules caused by their individual isoelectric points of $\mathrm{pH}$ 6.8-8.5 and $\mathrm{pH}$ 5.7-6 (Thanh \& Shibasaki, 1976) respectively. In brief: these subunits begin to aggregate as their individual charges decline, starting to form a network by bringing individual molecules closer together. In our experiments, this accounts for the initial first increase in gel strength at $\mathrm{pH}$ 6. However, at this $\mathrm{pH}$ value, the overall electrostatic repulsion is strong enough to prevent uncontrolled aggregation of the acidic legumin subunits and the remaining vicilin units. This can be supported by SEM micrographs at 300-fold magnification (figure 3 a), which shows an overall percolated network.

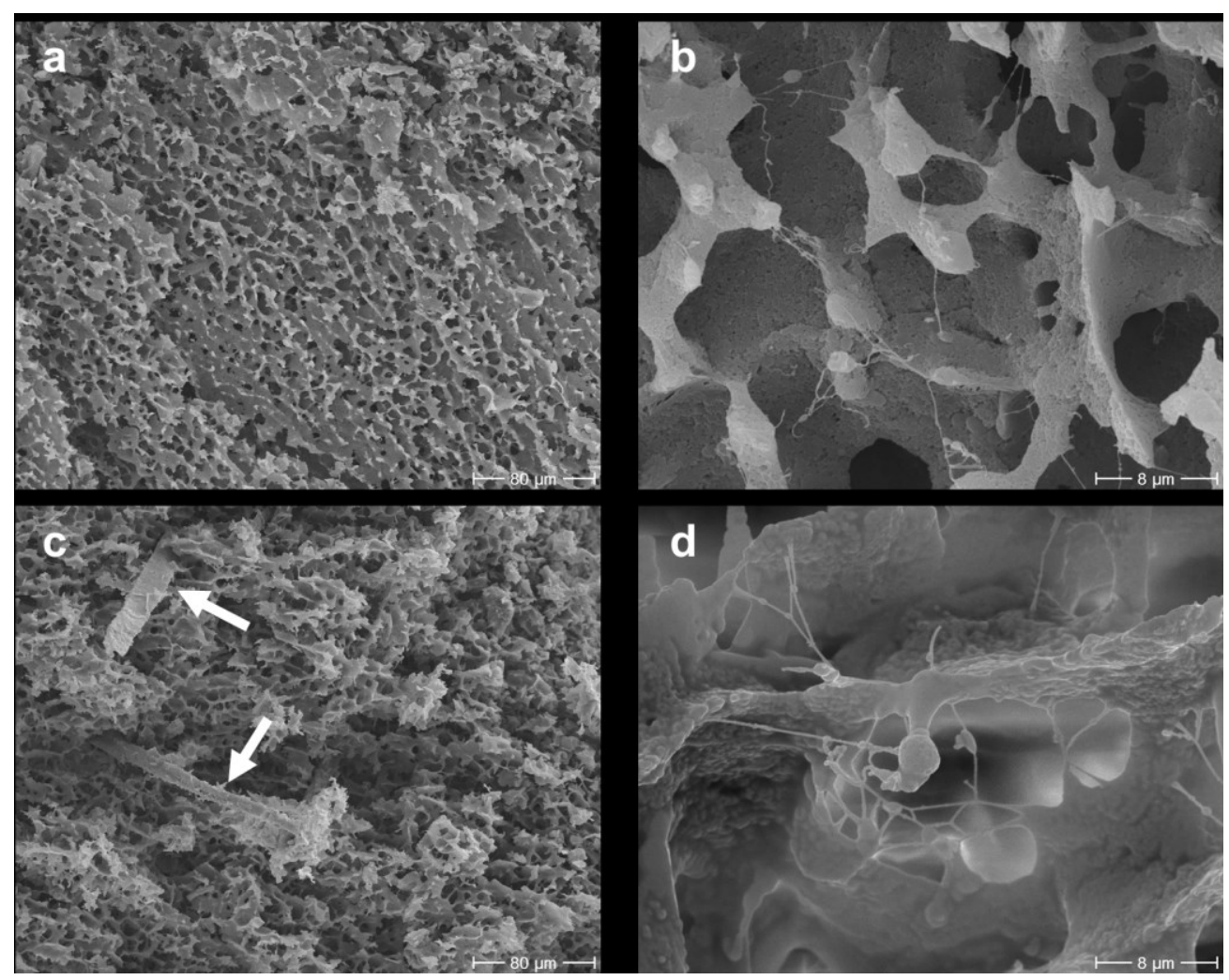

Fig 3 SEM images of fermented pea protein gels. SEM of pea protein only at 300-fold (a) and 3000-fold (b) magnification, SEM of pea protein supplemented with fibre at 300-fold (c) and supplemented with oil at 3000-fold (d) magnification.

Similar structures were found by (Yang, Wang, \& Chen, 2017) for the acid induced gelation of oat protein by glucono- $\delta$-lactone, even though in their case the underlying mechanism was described differently. As the $\mathrm{pH}$ decreased further, charges on the more acidic subunits reduced as they approached their isoelectric points. This in turn led to the formation of further intermolecular bonds and the pronounced increase in $\mathrm{G}^{\prime}$ at $\mathrm{pH}$ values below 5.5. Most likely, this also led to the condensation of small 
aggregates at the previously formed structures leading to the rough appearance of the structure-surface in SEM pictures at 3000-fold magnification (figure $3 \mathrm{~b}$ ).

Despite no significant differences in $\mathrm{pH}$ curves, samples containing oil and/or fibre showed an increased structuring velocity. This increase could be correlated $(\mathrm{R}=0.97)$ to the relative protein concentration in the samples and was therefore more pronounced if samples contained fibre. This is well in agreement with Azim et al., 2010 who reported similar behaviour in samples where modified starch immobilised some of the continuous phase, thus increasing the relative protein concentration. Moreover, the relative protein concentration also correlated with the values of $\left|G^{*}\right|$ at various times throughout the fermentation process and subsequent storage (supplementary material). We therefore propose the increase in relative protein concentration to be the main cause for the increase in structuring velocities and $\left|\mathrm{G}^{*}\right|$ values.

Additionally, in samples containing fibre $\tan \delta$ values were $<1$ (table 3 ) from the beginning of fermentation indicating a gel like structure throughout. On the one hand, this may have been caused by the increased relative protein content; on the other hand, fibres themselves may have been responsible for this effect. The general structuring behaviour of cellulose-rich fibre in aqueous environment was summarised by Kerekes, 2006. The author explains different models to describe restraint imposed on translational and rotational motion of individual fibres. In contrast to hydrocolloid and protein gels, the attracting effects in network-formation of fibre are mainly mechanic and are divided into hooking and friction (Derakhshandeh, Kerekes, Hatzikiriakos, \& Bennington, 2011; Kerekes, 2006). In our samples, hooking and friction probably caused the formation of an initial fibre network, in turn leading to $\tan \delta$ values $<1$ even before the start of fermentation. As fermentation proceeded, the protein network started to form analogously to samples without added fibre, became dominant, and led to a continuous structure with embedded fibres (figure $3 \mathrm{c}$ ). Within the protein network the fibre acts as nearly inactive filler due to its non-ionic and hydrophilic nature as previously described for starch by Corredig, Sharafbafi, \& Kristo, 2011 and is therefore believed not to interact with the protein-network on a relevant scale. Domination of the protein network is further supported by the lack of significant differences in $\tan \delta$ between supplemented and unsupplemented samples. This is in agreement with results on yoghurt enriched with functional asparagus fibre, where the authors came to the conclusion, that the addition of fibre did not modify the structural organisation or the type of molecular interactions (Sanz et al., 2008).

When rapeseed oil was added to the samples, the oil was emulsified by the protein during the homogenisation step before fermentation. From a previous study (Klost \& Drusch, 2019) we know that a protein content of $1 \%$ is sufficient to stabilise $5 \%$ rapeseed oil. Samples in the current study contained $10 \%$ protein and $4 \%$ oil, leading to sufficient bulk protein for network formation. Consequently, these samples were expected to form filled emulsion gels where oil droplets are embedded in a continuous protein matrix as described by Dickinson, 2012. In the context of emulsion gels, literature usually considers protein-stabilised oil-droplets as active fillers due to their affinity to the gel matrix (Dickinson, 2012). In our study, during emulsification the pea protein stabilised small droplets of rapeseed oil by migrating to and unfolding and adsorbing at the interface (Damodaran, 2005). The extent of unfolding of soy protein at the interface was previously described to exceeded that of previous temperature induced unfolding (Miriani et al., 2011) and led to the exposure of buried hydrophobic areas. These areas orient towards the oil-phase (Wilde, Mackie, Husband, Gunning, \& Morris, 2004), while the charged areas point toward the aqueous phase (Ducel, Richard, Popineau, \& Boury, 2004). At the same time the surface denaturation may also cause an increase in surface hydrophobicity of the emulsion droplets (Kim, Decker, \& McClements, 2002). Despite the change in interfacial protein conformation, due to the excess of bulk protein, the increase in relative protein concentration was still the main reason for increased structuring velocity and values for $\left|\mathrm{G}^{*}\right|$ upon addition of oil. During the structuring process protein-covered oil droplets were embedded in the protein-matrix leading to the blistery appearance in SEM pictures (figure $3 \mathrm{~d}$ ). If both oil and fibre were added fibre was incorporated between the protein 
network (inactive filler) and the oil (active filler) leads to a blistery appearance of the protein network itself (pictures shown in supplementary material, figure 8).

\subsection{Rheological characterisation of the fully set gels}

This section covers the values for $\left|\mathrm{G}^{*}\right|$ and $\tan \delta$ after storage for 24 hours at $4^{\circ} \mathrm{C}$. Moreover, behaviour of the fully set gels in thixotropy tests, amplitude and penetration tests (large strain deformation) and frequency sweeps (small strain deformation testing), was investigated.

As a result of some structural rearrangements upon resting and cooling $\left|\mathrm{G}^{*}\right|$ and $\tan \delta$ increased by approximately $1.5 \%$ and $1.7 \%$ respectively (table 3 ) during storage at $4{ }^{\circ} \mathrm{C}$ for $24 \mathrm{~h}$. The complex shear modulus increased due to the formation of more but probably very weak interactions leading to a more pronounced rise in the loss modulus G' than in the storage modulus G' and therefore to larger values of $\tan \delta$. Supplementation with oil significantly reduced $\tan \delta$ by approx. $4 \%$ (table 3 ), while $\left|\mathrm{G}^{*}\right|$ was unaffected. The decrease in $\tan \delta$ indicated a slight increase in elastic contributions to $\left|\mathrm{G}^{*}\right|$ and is ascribed to the active filler properties of the oil. In a study on heat set whey protein emulsion gels active fillers decreased $\tan \delta$ due to a less homogenous distribution of crosslinks in emulsified gels and in turn restricted the amount of viscous dissipation in small strain testing (Dickinson \& Chen, 1999). In a different study the supplementation with varying amounts of oils to heat set soy-protein emulsions reduced $\tan \delta$ with increasing oil concentrations (Gu et al., 2009). However, it is also known that active fillers increase the storage modulus G' (Ben-Harb et al., 2017). This effect was dependent on the absolute magnitude of G' and references showed an increase in G' of approx. $20 \%$ at an oil to protein ratio of 5:6, steeply increasing at higher ratios (Dickinson \& Chen, 1999). The small but significant decrease in $\tan \delta$ in our study is in agreement with the described effects. The low ratio of oil to protein $(2: 5)$ is the reason for the small reduction in $\tan \delta$.

In thixotropy measurements (figure $4 \mathrm{a}$ ), the gel was oscillated at parameters within the linear viscoelastic regime, consecutively sheared and again oscillated. The results (table 4) showed that intense shearing destroyed parts of the structure of the system irreversibly, while other parts restructured. Overall, G' and G' regained around $60 \%$ of their former value in samples without fibre and around $50 \%$ in samples with fibre (table 5). All samples attained a gel state throughout the oscillation part of the experiment, as indicated by $\tan \delta<1$. This indicated that restructuring occurred immediately after shearing and was not detectable in the experiment. Loss of structure after shearing was more pronounced in samples with fibre and may in all cases be attributed to the initial formation of smooth, linear structures at $\mathrm{pH}$ away from the isoelectric point during fermentation. At the $\mathrm{pH}$-value of the set gels, the protein initially involved in the linear structure would re-associate in a more disordered manner after structure destruction thus lowering G' and G'. If fibres were present, these may have hindered some of the restructuring.

In amplitude sweeps (figure $4 \mathrm{~b}$ ) the deformations at the maximum strain (table 4 ) within the linear viscoelastic regime did not differ significantly between the samples but were slightly lower in samples containing fibre which may be attributed to fibres' ability to disrupt inter-protein bonds (Espírito-Santo et al., 2013; Sendra et al., 2010). With values between $0.74 \%$ (PF) and $1.26 \%$ (PO) the maximum strains within the linear viscoelastic regime were found to be clearly below the required strain resistance for strong gels (up to at least $\gamma=25 \%$ proposed by Ross-Murphy \& Shatwell, 1993) and the curve from the amplitude sweep gradually declined indicating a development towards flowing. This is also consistent with penetration tests where it was not possible to determine a classical breaking point (results not shown). 

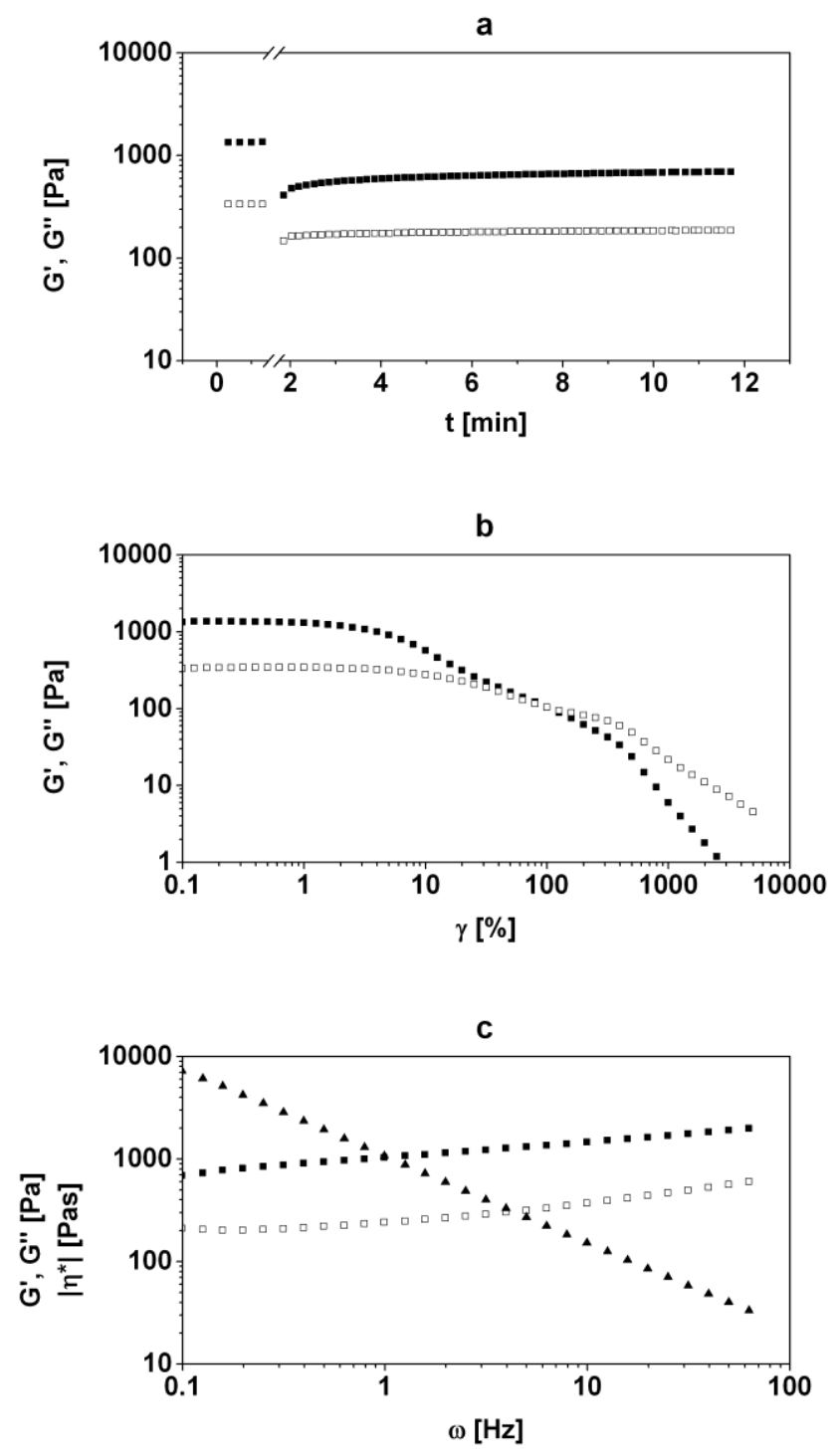

Fig 4 rheological properties of fermented pea protein gels after $24-30 \mathrm{~h}$ storage $\left(6^{\circ} \mathrm{C}\right)$. Thixotropy test (a), amplitude sweep (b) and frequency sweep (c) of samples containing oil and fibre ( $\left.\square G^{\prime}, \square G^{\prime},, \boldsymbol{\Delta}\left|\eta^{*}\right|\right)$.

Results from frequency sweeps (figure $4 \mathrm{c}$, table 5) were close to the behaviour of true gels:

- G' showed values approximately four times larger than G" with some deviations at high frequencies. This indicates gel characteristics throughout the sweep.

- G' and G' ' increased with slopes (dlogG'/dlog $\omega$ and $d \log G / d \log \omega)$ of 0.15 (G', POF) to 0.2 $(G$ ' $P$ ), indicating a small frequency dependence of similar magnitude for all samples despite a significant decrease with increasing supplementation.

- The slopes of $d \log \mid \eta^{*} / / \operatorname{dog} \omega$ were between -0.81 (P) and -0.84 (POF) Pas/Hz in the doublelogarithmic plot with significantly higher values in supplemented samples. These were however still of similar magnitude to each other.

- The decrease in slopes of G' and G' as well as the increase in slope of $\left|\eta^{*}\right|$ can again be correlated to the relative protein content $(\mathrm{R}=-0.885, \mathrm{R}=-0.983$ and $\mathrm{R}=-0.877$ respectively) 


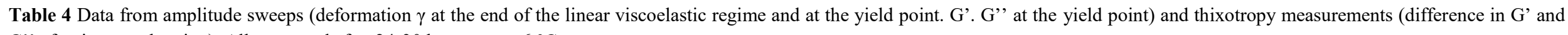
G' after intense shearing). All measured after $24-30 \mathrm{~h}$ storage at $6{ }^{\circ} \mathrm{C}$.

(Samples: $\mathrm{P}=$ pea protein, $\mathrm{PO}=$ pea protein and rapeseed-oil, $\mathrm{PF}=$ pea protein and fibre, $\mathrm{POF}=$ pea protein, rapeseed-oil and fibre)

\begin{tabular}{|c|c|c|c|c|c|c|}
\hline Sample & $\begin{array}{c}\gamma_{\text {end of linear viscoelastic }} \\
\text { regime }[\%]\end{array}$ & $\gamma_{\text {yield point }}[\%]$ & $\mathrm{G}^{\prime}, \mathrm{G}^{\prime}{ }^{\prime}$ yield point $[\mathrm{Pa}]$ & $\Delta G^{6}[\%]$ & & $\mathrm{G}^{66}[\%]$ \\
\hline $\mathrm{P}$ & $1.21^{\mathrm{a}} \pm 0.40$ & $68.6^{a} \pm 9$ & $72^{a} \pm 4$ & $39.1^{\mathrm{a}} \pm 1.15$ & $38.7^{\mathrm{a}, \mathrm{c}}$ & \pm 1.62 \\
\hline $\mathrm{PO}$ & $1.26^{\mathrm{a}} \pm 0.00$ & $56.5^{\mathrm{a}} \pm 21$ & $98^{\mathrm{a}} \pm 24$ & $35.5^{\mathrm{a}} \pm 2.15$ & $33.9^{\mathrm{a}}$ & \pm 2.18 \\
\hline PF & $0.74^{\mathrm{a}} \pm 0.09$ & $86.3^{\mathrm{a}} \pm 12$ & $88^{\mathrm{a}} \pm 14$ & $51.2^{\mathrm{b}} \pm 2.04$ & $49.7^{\mathrm{b}, \mathrm{c}}$ & \pm 1.83 \\
\hline POF & $1.00^{\mathrm{a}} \pm 0.00$ & $93.2^{\mathrm{a}} \pm 12$ & $105^{\mathrm{a}} \pm 9$ & $48.5^{\mathrm{b}} \pm 1.73$ & $44.3^{c}$ & \pm 2.52 \\
\hline
\end{tabular}

*Different letters within a column denote significant differences between individual samples as found by one factorial ANOVA followed by Tukey postHoc Test

Table 5 Data from frequency sweeps (slopes of $\log G^{\prime}, \log G^{\prime}$, and $\log \left|\eta^{*}\right|$ versus $\log \omega$ ).

(Samples: $\mathrm{P}=$ pea protein, $\mathrm{PO}=$ pea protein and rapeseed-oil, $\mathrm{PF}=$ pea protein and fibre, $\mathrm{POF}=$ pea protein, rapeseed-oil and fibre)

\begin{tabular}{|c|c|c|c|c|}
\hline Sample & $d \log G^{\prime} / d \log \omega$ & dlogC & 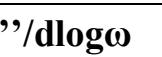 & $\operatorname{dlog}|\eta *| / d \log \omega$ \\
\hline $\mathrm{P}$ & $0.192^{\mathrm{a}} \pm 0.005$ & $0.200^{\mathrm{a}}$ & 0.004 & $-0.810^{\mathrm{a}} \pm 0.004$ \\
\hline $\mathrm{PO}$ & $0.183^{\mathrm{a}, \mathrm{b}} \pm 0.002$ & $0.188^{\mathrm{a}, \mathrm{b}}$ & 0.021 & $-0.817^{\mathrm{a}, \mathrm{b}} \pm 0.003$ \\
\hline $\mathrm{PF}$ & $0.179^{b} \pm 0.004$ & $0.168^{b}$ & 0.011 & $-0.823^{b} \pm 0.005$ \\
\hline POF & $0.163^{c} \pm 0.005$ & $0.155^{\mathrm{c}}$ & 0.008 & $-0.840^{\mathrm{c}} \pm 0.002$ \\
\hline
\end{tabular}

*Different letters within a column denote significant differences between individual samples as found by one factorial ANOVA followed by Tukey postHoc Test 
Even though these values are close to those described for true gels, they do not quite meet them. Despite the fairly low influence of frequency on G' and G' they differ by less than an order of magnitude and even though $d \log \mid \eta^{*} / / \operatorname{dog} \omega$ shows linear behaviour, its slope distinctly differs from -1 and may be caused by the high protein content of the samples rather than by actual true gel properties. Liu \& Tang, 2011 and C. H. Tang \& Liu, 2013 reported similar slight but progressive increases of G' with increasing frequency in gel-like whey and soy protein emulsions and linked it to a non-covalently cross-linked gelstructure. They also concluded, that even though $\tan \delta$ was almost independent of frequency its values of around 0.3 indicated weak (and predominantly viscous) gels.

Given, that acidified protein generally tends to form gels via non-covalent bonds, we can assume, that despite the near true gel like behaviour in frequency sweeps, the gel investigated in our study can generally be considered weak in nature as confirmed by amplitude sweeps and large deformation rheology. The rheological behaviour of samples containing oil is close to an emulsion-filled protein gel as the results show a clear dominance of the protein-network (Dickinson, 2012) and the supplementation with fibre did only marginally influence parameters in frequency and amplitude sweeps. We therefore come to the conclusion, that supplementation with oil and/or fibre only had minor effects on the rheological properties of the samples which was consequently dominated by the protein network.

\section{Conclusions}

In all investigated samples pea protein was able to form gels upon fermentation after being heated to $60{ }^{\circ} \mathrm{C}$ (holding time 60 minutes). We assume a two-phase gelation process comprising the association of pea protein units with high isoelectric points into a linear and overall percolated network structure followed by condensation of aggregates at the structure-surface at the subsequent fast $\mathrm{pH}$ decline leading to an increased gel strength. Supplementation with oil and/or fibre increased the maximum structuring velocity of the developing protein-network due to an increase in the relative protein concentration. During refrigerated storage some structural rearrangements occurred, mainly due to the formation of weak non-covalent links, which increased the viscous proportions of the gel. Rheological tests showed mostly weak gel properties. The protein network was the dominating structure, even though incorporated oil increased the elastic proportion of the system. Added fibre significantly increased $\left|\mathrm{G}^{*}\right|$ due to increased net protein concentration and initial hooking and friction effects. Mostly, oil and fibre did not show any synergistic effects if added in combination but their effects coexisted. Therefore, pea protein was found to be a suitable alternative base for plant protein based yoghurt alternatives. Moreover, the attained gels could be further supplemented with nutritionally valuable rapeseed oil and/or oat fibre, making them a promising approach for nutritional strategies related to improvement of health and well-being in general and healthy aging in particular. From a consumer's point of view, sensorial shortcomings of the pea protein yoghurt alternatives are the most important issue to be addressed in the future. Besides this, it is worthwhile to further investigate the material scientific properties of the system concerning clarification of the types of interactions involved in forming fermented pea protein gel systems and their respective contributions to the network.

Acknowledgments: The Authors gratefully acknowledge the skilful lab-work of J. Nissen (SEM).

Funding: This work was supported by NutriAct - Competence Cluster Nutrition Research BerlinPotsdam funded by the Federal Ministry of Education and Research (BMBF) (FKZ: 01EA1408C) 


\section{References}

Aportela-Palacios, A., Sosa-Morales, M. E., \& Vélez-Ruiz, J. F. (2005). Rheological and physicochemical behavior of fortified yogurt, with fiber and calcium. Journal of Texture Studies, 36(3), 333-349. https://doi.org/10.1111/j.1745-4603.2005.00020.x

Azim, Z., Alexander, M., Koxholt, M., \& Corredig, M. (2010). Influence of cross-linked waxy maize starch on the aggregation behavior of casein micelles during acid-induced gelation. Food Biophysics, 5(3), 227-237. https://doi.org/10.1007/s11483-010-9164-1

Banovic, M., Lähteenmäki, L., Arvola, A., Pennanen, K., Duta, D. E., Brückner-Gühmann, M., \& Grunert, K. G. (2018). Foods with increased protein content: A qualitative study on European consumer preferences and perceptions. Appetite, 125, 233-243. https://doi.org/10.1016/j.appet.2018.01.034

Ben-Harb, S., Panouillé, M., Huc-Mathis, D., Moulin, G., Saint-Eve, A., Irlinger, F., ... Souchon, I. (2017). The rheological and microstructural properties of pea, milk, mixed pea/milk gels and gelled emulsions designed by thermal, acid, and enzyme treatments. Food Hydrocolloids, 1-10. https://doi.org/10.1016/j.foodhyd.2017.09.022

Chen, J., \& Dickinson, E. (1998). Viscoelastic properties of heat-set whey protein emulsion gels. Journal of Texture Studies, 29(3), 285-304. https://doi.org/https://doi.org/10.1111/j.17454603.1998.tb00171.x

Chen, N., Zhao, M., Chassenieux, C., \& Nicolai, T. (2016a). Structure of self-assembled native soy globulin in aqueous solution as a function of the concentration and the $\mathrm{pH}$. Food Hydrocolloids, 56, 417-424. https://doi.org/10.1016/j.foodhyd.2015.12.028

Chen, N., Zhao, M., Chassenieux, C., \& Nicolai, T. (2016b). Thermal aggregation and gelation of soy globulin at neutral pH. Food Hydrocolloids, 61, 740-746. https://doi.org/10.1016/j.foodhyd.2016.06.028

Corredig, M., Sharafbafi, N., \& Kristo, E. (2011). Polysaccharide-protein interactions in dairy matrices, control and design of structures. Food Hydrocolloids, 25(8), 1833-1841. https://doi.org/10.1016/j.foodhyd.2011.05.014

Damian, C., \& Olteanu, A. (2014). Influence of dietary fiber from pea on some quality characteristics of yoghurts. Journal of Agroalimentary Processes and Technologies, 20(2), 156-160.

Damodaran, S. (2005). Protein Stabilization of Emulsions and Foams. Food Science, 70(3), 54-66. https://doi.org/10.1111/j.1365-2621.2005.tb07111.x

Danielsson, C.-E. (1950). An Electrophoretic Investigation of Vicilin and Legumin from Seeds of Peas. Acta Chemica Scandinavica, 4, 762-771.

Day, L. (2013). Proteins from land plants - Potential resources for human nutrition and food security. Trends in Food Science and Technology, 32(1), 25-42. https://doi.org/10.1016/j.tifs.2013.05.005

Denkova, Z., Yanakieva, V., Denkova, R., Dobrev, I., \& Kozludzhova, S. (2013). Examining the possibilities for application of pea milk in obtaining fermented probiotic foods. Scientific Work of the Russion University, 52(10.2), 31-35.

Derakhshandeh, B., Kerekes, R. J., Hatzikiriakos, S. G., \& Bennington, C. P. J. (2011). Rheology of pulp fibre suspensions: A critical review. Chemical Engineering Science, 66(15), 3460-3470. https://doi.org/10.1016/j.ces.2011.04.017

Dickinson, E. (2012). Emulsion gels: The structuring of soft solids with protein-stabilized oil droplets. Food Hydrocolloids, 28(1), 224-241. https://doi.org/10.1016/j.foodhyd.2011.12.017

Dickinson, E., \& Chen, J. (1999). Heat-Set Whey Protein Emulsion Gels: Role of Active and Inactive Filler Particles. Journal of Dispersion Science and Technology, 20(1-2), 197-213. https://doi.org/10.1080/01932699908943787

DIN SPEC 91143-2. (2012).

DIN Technical Report No. 143. (2005). 
Ducel, V., Richard, J., Popineau, Y., \& Boury, F. (2004). Adsorption kinetics and rheological interfacial properties of plant proteins at the oil-water interface. Biomacromolecules, 5(6), 2088-2093. https://doi.org/10.1021/bm049739h

Espírito-Santo, A. P., Lagazzo, A., Sousa, A. L. O. P., Perego, P., Converti, A., \& Oliveira, M. N. (2013). Rheology, spontaneous whey separation, microstructure and sensorial characteristics of probiotic yoghurts enriched with passion fruit fiber. Food Research International, 50(1), 224-231. https://doi.org/10.1016/j.foodres.2012.09.012

European Food Safety Authority. (2010a). Scientific Opinion on Dietary Reference Values for $\begin{array}{llllll}\text { carbohydrates and dietary fibre. EFSA Journal, } & \text { 8(3), }\end{array}$ https://doi.org/10.2903/j.efsa.2010.1462.Available

European Food Safety Authority. (2010b). Scientific opinion on dietary reference values for fats, including saturated fatty acids, polyunsaturated fatty acids, monounsaturated fatty acids, trans fatty acids, and cholesterol. EFSA Journal, 8(3), 1461. https://doi.org/10.2903/j.efsa.2010.1461.

Fernández García, E., \& McGregor, J. U. (1997). Fortification of sweetened plain yogurt with insoluble dietary fiber. Zeitschrift Für Lebensmittel-Untersuchung Und -Forschung, 204(6), 433-437. https://doi.org/10.1007/s002170050108

Grosso, C. R. ., \& Rao, M. . (1998). Dynamic rheology of structure development in low-methoxyl pectin+Ca2++sugar gels. Food Hydrocolloids, 12(3), 357-363. https://doi.org/10.1016/S0268005X(98)00034-4

Grygorczyk, A., \& Corredig, M. (2013). Acid induced gelation of soymilk, comparison between gels prepared with lactic acid bacteria and glucono- $\delta$-lactone. Food Chemistry, 141(3), 1716-1721. https://doi.org/10.1016/j.foodchem.2013.03.096

Gu, X., Campbell, L. J., \& Euston, S. R. (2009). Effects of different oils on the properties of soy protein isolate emulsions and gels. Food Research International, 42(8), 925-932. https://doi.org/10.1016/j.foodres.2009.04.015

Hirose, M. (1993). Molten globule state of food proteins. Trends in Food Science \& Technology, 4, 4851.

Keogh, M. K., \& O'Kennedy, B. T. (1998). Rheology of Stirred Yogurt as Affected by Added Milk Fat, Protein and Hydrocolloids. Journal of Food Science, 63(1), 108-112. https://doi.org/10.1111/j.1365-2621.1998.tb15687.x

Kerekes. (2006). Rheology of fibre suspensions in papermaking: An overview of recent research. Nordic Pulp and Paper Research Journal, 21(05), 598-612. https://doi.org/10.3183/NPPRJ-2006-21-05p598-612

Kim, H.-J., Decker, E. A., \& McClements, D. J. (2002). Impact of Protein Surface Denaturation on Droplet Flocculation in Hexadecane Oil-in-Water Emulsions Stabilized by $\beta$-Lactoglobulin. Journal of Agricultural and Food Chemistry, 50(24), 7131-7137. https://doi.org/10.1021/jf020366q

Klost, M., \& Drusch, S. (2019). Functionalisation of pea protein by tryptic hydrolysis - Characterisation of interfacial and functional properties. Food Hydrocolloids, 86, 134-140. https://doi.org/10.1016/j.foodhyd.2018.03.013 
Kohyama, K., Sano, Y., \& Doi, E. (1995). Rheological Characteristics and Gelation Mechanism of Tofu (Soybean Curd). Journal of Agricultural and Food Chemistry, 43(7), 1808-1812. https://doi.org/10.1021/jf00055a011

Krajcovicova-Kudlackova, M., Babinska, K., \& Valachovicova, M. (2005). Health benefits and risks of plant proteins. Bratislavské Lekárske Listy., 106(6-7), 231-234.

Krämer, J. (1997). Lebensmittel-Mikrobiologie (3. Edition). Ulmer.

Lee, W. J., \& Lucey, J. A. (2010). Formation and physical properties of yoghurt. Asian-Australasian Journal of Animal Science, 23(9), 1127-1136. https://doi.org/10.5713/ajas.2010.r.05

Li, F., Kong, X., Zhang, C., \& Hua, Y. (2012). Gelation behaviour and rheological properties of acidinduced soy protein-stabilized emulsion gels. Food Hydrocolloids, 29(2), 347-355. https://doi.org/10.1016/j.foodhyd.2012.03.011

Liu, F., \& Tang, C. H. (2011). Cold, gel-like whey protein emulsions by microfluidisation emulsification: Rheological properties and microstructures. Food Chemistry, 127(4), 1641-1647. https://doi.org/10.1016/j.foodchem.2011.02.031

Lucey, J. A., \& Singh, H. (1997). Formation and physical properties of acid milk gels: A review. Food Research International, 30(7), 529-542. https://doi.org/10.1016/S0963-9969(98)00015-5

McCann, T. H., Fabre, F., \& Day, L. (2011). Microstructure, rheology and storage stability of low-fat yoghurt structured by carrot cell wall particles. Food Research International, 44(4), 884-892. https://doi.org/10.1016/j.foodres.2011.01.045

Mession, J. L., Chihi, M. L., Sok, N., \& Saurel, R. (2015). Effect of globular pea proteins fractionation on their heat-induced aggregation and acid cold-set gelation. Food Hydrocolloids, 46, 233-243. https://doi.org/10.1016/j.foodhyd.2014.11.025

Mezger, T. G. (2006). Das Rheologie Handbuch (2nd ed.). Vencentz Verlag.

Miriani, M., Keerati-u-rai, M., Corredig, M., Iametti, S., \& Bonomi, F. (2011). Denaturation of soy proteins in solution and at the oil-water interface: A fluorescence study. Food Hydrocolloids, 25(4), 620-626. https://doi.org/10.1016/j.foodhyd.2010.07.020

Morris, E. R., Nishinari, K., \& Rinaudo, M. (2012). Gelation of gellan - A review. Food Hydrocolloids, 28(2), 373-411. https://doi.org/10.1016/j.foodhyd.2012.01.004

Ross-Murphy, S. B., \& Shatwell, K. P. (1993). Polysccharide strong and weak gels. Biorheology, 30(2), $217-222$. 
Sah, B. N. P., Vasiljevic, T., McKechnie, S., \& Donkor, O. N. (2016). Physicochemical, textural and rheological properties of probiotic yogurt fortified with fibre-rich pineapple peel powder during refrigerated storage. LWT - Food Science and Technology, 65, 978-986. https://doi.org/10.1016/j.lwt.2015.09.027

Sanz, T., Salvador, A., Jiménez, A., \& Fiszman, S. M. (2008). Yogurt enrichment with functional asparagus fibre. Effect of fibre extraction method on rheological properties, colour, and sensory acceptance. European Food Research and Technology, 227(5), 1515-1521. https://doi.org/10.1007/s00217-008-0874-2

Sendra, E., Kuri, V., Fernández-López, J., Sayas-Barberá, E., Navarro, C., \& Pérez-Alvarez, J. A. (2010). Viscoelastic properties of orange fiber enriched yogurt as a function of fiber dose, size and thermal treatment. LWT - Food Science and Technology, 43(4), 708-714. https://doi.org/10.1016/j.lwt.2009.12.005

Tang, C., Chen, L., \& Foegeding, E. A. (2011). Mechanical and Water-Holding Properties and Microstructures of Soy Protein Isolate Emulsion Gels Induced by $\mathrm{CaCl} 2$, Glucono- $\delta$-lactone ( GDL ), and Transglutaminase: Influence of Thermal Treatments before and / or after Emulsification. Journal of Agricultural and Food Chemistry, 59, 4071-4077. https://doi.org/dx.doi.org/10.1021/jf104834m

Tang, C. H., \& Liu, F. (2013). Cold, gel-like soy protein emulsions by microfluidization: Emulsion characteristics, rheological and microstructural properties, and gelling mechanism. Food Hydrocolloids, 30(1), 61-72. https://doi.org/10.1016/j.foodhyd.2012.05.008

Thanh, V. H., \& Shibasaki, K. (1976). Major Proteins of Soybean Seeds. A Straightforward Fractionation and Their Characterization. Journal of Agricultural and Food Chemistry, 24(6), 1117-1121. https://doi.org/10.1021/jf60208a030

Wilde, P., Mackie, A., Husband, F., Gunning, P., \& Morris, V. (2004). Proteins and emulsifiers at liquid interfaces. Advances in Colloid and Interface Science, 108-109, 63-71. https://doi.org/10.1016/j.cis.2003.10.011

Yang, C., Wang, Y., \& Chen, L. (2017). Fabrication, characterization and controlled release properties of oat protein gels with percolating structure induced by cold gelation. Food Hydrocolloids, 62, 21-34. https://doi.org/10.1016/j.foodhyd.2016.07.023

Yousseef, M., Lafarge, C., Valentin, D., Lubbers, S., \& Husson, F. (2016). Fermentation of cow milk and/or pea milk mixtures by different starter cultures: Physico-chemical and sensorial properties. LWT - Food Science and Technology, 69, 430-437. https://doi.org/10.1016/j.1wt.2016.01.060

Zare, F., Boye, J. I., Champagne, C. P., Orsat, V., \& Simpson, B. K. (2013). Probiotic Milk Supplementation with Pea Flour: Microbial and Physical Properties. Food and Bioprocess Technology, 6(5), 1321-1331. https://doi.org/10.1007/s11947-012-0828-3 